\title{
Tissue Specific Expression of Wound-Inducible RCaM-2 Promoter in Transgenic Tobacco Plants
}

\author{
Young Ju Choi* \\ Department of Food and Nutrition, Silla University, Busan 617-736, Korea. \\ Received January 6, 2005 / Accepted February 7, 2005
}

\begin{abstract}
To study calmodulin ( $\mathrm{CaM}$ ) gene expression and its regulation, rice CaM promoter (RCaM-2) was isolated and fused to $\beta$-glucuronidase (GUS), reporter gene. X-Gluc staining patterns revealed that GUS localization is high in meristemic tissues such as the stem apex, stolen tip, and vascular regions. GUS staining in the transverse sections of stem and petiole was restricted to the inside of the vascular system, and cortex and epidermis located outside of the vascular system usually did not show GUS staining even a plant that expressed strong activity. GUS activity was found to be tissue specific expressed and exhibited a dramatic transient increase in response to wounding. These results suggest that the 5 '-flanking region of RCaM gene regulates wound-inducible expression.
\end{abstract}

Key words - calmodulin promoter, wounding, histochemical localization

The ability to respond to extracellular signals is essential for the development and survival, of all living organism, to adapt to changing and adverse environmental conditions. One of the severest environmental stresses to which plants may be subjected is wounding, which may come about through such diverse causes as mechanical injury or herbivore attack. Thus, plant cells perceive a various signals from their surrounding, and convert them into a cellular response via signal transduction pathways.

Calmodulin known as multifunctional regulatory protein is a highly conserved protein and it interacts with other proteins in the cell and regulate their activity. In plants, the activities of several enzymes such as protein kinase, NAD-kinase, glutamate decarboxylase, and $\mathrm{Ca}^{2+}$-ATPase are known to be regulated by calmodulin and calmodulin related protein[24,29,36].

Several CaM and CaM-related genes have been described in high plants such as Arabidopsis thaliana[3,9,22], potato[30], soybean[18], wheat[34], tobacco[33] and rice[6]. The diversity of $\mathrm{CaM}$ or CaM-related genes raised questions concerning their function, regulation and evolution. Plant $\mathrm{CaM}$ isoforms showed different functions for calcium-binding abilities and activation of CaM-dependent enzymes $[11,18,19]$ Recently, it has been proposed that specific soybean CaM isoforms are components of SA-independent signal transduction chain leading to disease resistance[11]. The calmodulin-like proteins were also identified novel

\section{*Corresponding author}

Tel : +82-51-999-5459, Fax : +82-51-999-5687

E-mail : yjchoi@silla.ac.kr calmodulins with an extended C-terminal basic domain and CaaV-box motifs which are required for efficient prenylation of the protein[27,32].

The expression of calmodulin isoforms is known to be differentially regulated by a variety of signals such as hormones and chemicals[4,7,14] CaM gene expression was also regulated in developmental and an organ-specific manner during the plant growth[7,30,35]. The high level of CaM protein and mRNA generally are observed in proliferating populations of cultured cells and in plant meristematic regions including the shoot apex, stolen tip, and vascular tissues[30,32]. The expression of calmodulin mRNA is also induced by mechanical stresses such as touching and wounding in plants $[1,2,3,30]$. However, how plants recognize most environmental stimuli is poorly understood. The molecular mechanisms regulating wounding inducible expression of calmodulin genes have not been understood.

To investigate how plants sense and respond to wounding, we focus on the expression of the rice calmodulin promoters. We have characterized using transgenic plants carrying two different calmodulin promoters fused to the GUS reporter gene. The regulation of developmental and wound-induced calmodulin gene expression was studied in transgenic tobacco plants during the plant growth. Furthermore, tissue specific expression was studied in the root tip, stem, and petiole of young transgenic tobacco plants.

\section{Materials and Methods}

\section{Bacterial strains and materials}

The Escherichia coli host strain used for the gene mani- 
pulation of RCaM-2 promoters was XIL1-Blue (Stratagene). Agrobacterium tumefaciens strain LBA4404, which carries helper Ti plasmid pAL4404[12], was used for maintenance of plasmids and transformation of tobacco leaves. The plasmid pAL4404 is an avirulent derivative of the octopine $\mathrm{Ti}$ plasmid Ach 5 obtained by deletion of the entire transfer DNA (T-DNA) that carries the tumor genes. RCaM-2 promoterGUS fusion gene was constructed using a Ti-binary vector plasmid PBI101.2 containing the ß-glucuronidase (GUS) reporter gene. Tobacco plants (Nicotiana tabacum L. cv. Xanthi) were maintained on MS[23] agar medium as sterile shoot cultures.

\section{Construction of the Plant expression Vector}

RCaM promoter-GUS fusion gene was constructed using a promoter exoression vector $\mathrm{pBI} 101.2$ the $\beta$-glucuronidase (GUS) reporter gene as described in Fig. 1. The RCaM-2 promoter region was digested with $\mathrm{NcOl}$ and treated with Klenow fragment to give a blunt end, and cut with HindIII. RCaM promoter fragment was ligated into the HindIIISmaI digested pBI101.2 to generate pMB 302. Nucleic acid manipulation was done as described by Maniatis et al.[28].

\section{Plant transformation}

The RCaM promoter-GUS fusion gene was transferred by the directed DNA transfer method to the Agrobacterium tumefaciens strain LBA4404, which was used for the transformation of tobacco (Nicotiana tabacum L. cv. Xanthi) plants by the cocultivation method. Transformed cells and regenerated plantlets were selected on MS agar medium supplemented with $3 \%$ sucrose, $50 \mu \mathrm{g} / \mathrm{ml}$ kanamycin, and $250 \mu$ $\mathrm{g} / \mathrm{ml}$ carbenicillin.

Transgenic tobacco plants were grown in the green house at $25^{\circ} \mathrm{C} / 20^{\circ} \mathrm{C}$ days/night, under a $16 \mathrm{~h}$ photoperiod, and $65 \%$ relative humidity. About 2 -month-old transgenic plants grown in the greenhouse were used to study wound response and tissue specificity.

\section{Histochemical analysis of $\beta$-glucuronidase activity}

The expression of tissue specific and wound-inducible of CaM promoters was performed utilizing several organs and tissues at different stages of plant development in transgenic tobacco plants. Histochemical staining for GUS activity was performed according to the procedure of Jefferson with the modifications proposed by Koltunow[16]. Whole Leaves and different plant organ samples were fixed for 30

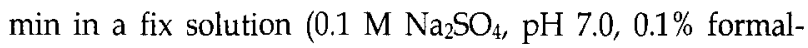
dehyde, $0.1 \%$ Triton $\mathrm{X}-100$, and $0.1 \%$ 2-mercaptoethanol)

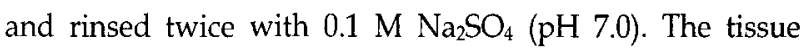
samples were incubated in a staining solution of $1 \mathrm{mM}$ 5-bromo-4-chloro-3-indolyl- $\beta$-D-glucuronide (x-Glu) and 50 $\mathrm{mM} \mathrm{Na} \mathrm{SO}_{4},(\mathrm{pH} 7.0)$ at $37^{\circ} \mathrm{C}$ overnight. For chlorophyll removal, the tissues were soaked in $70 \%$ ethanol and the blue staining was scored visually.

Transverse and longitudinal sections of the petioles and stem are cut by hand with a scalpel. For wound induction studies, leaves were wounded with the syringe in several places on the leaf blade to 5 to $30 \mathrm{~mm}$, without crushing. Wound-induced expressions of RCaM-2 promoter-GUS fusion gene is compared. Stems and petioles were wounded by the syringe in a place on the tissues after cutting.

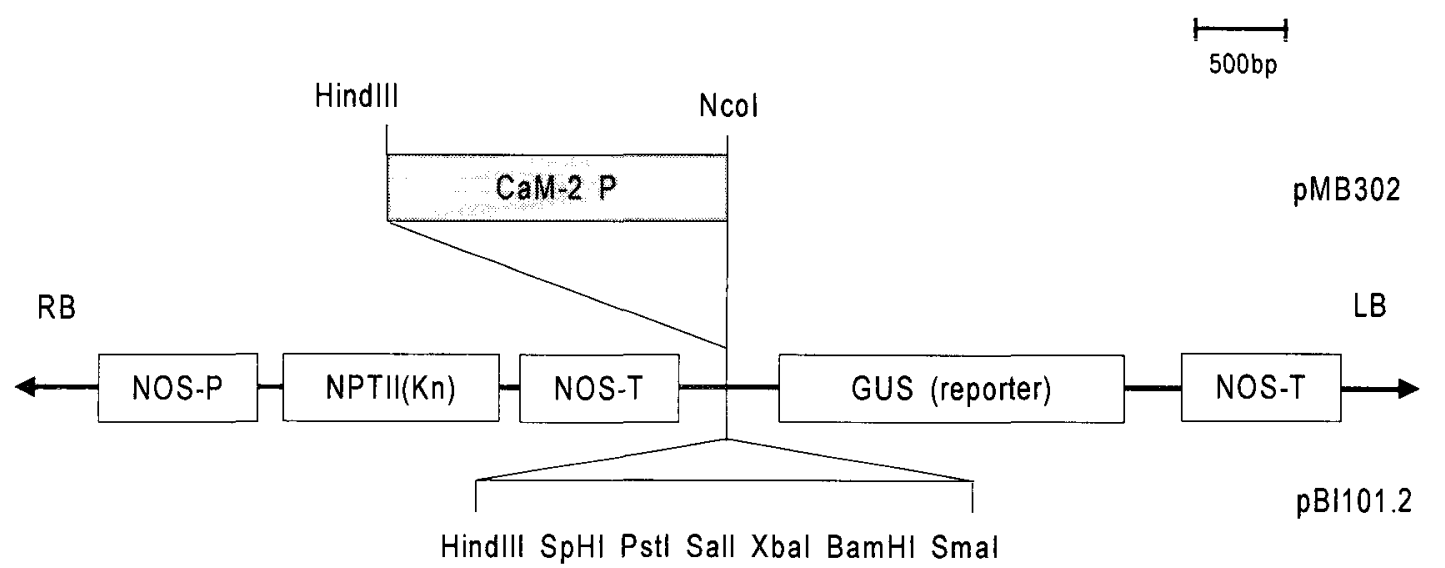

Fig. 1. Structure of plasmid used this study. Ti binary vector pBI101.2 containing the $\beta$-glucuronidase (GUS) reporter gene was digested with HindIII-SmaI, which is located at the upstream region of the GUS gene. The RCaM-2 promoter was digested with HindIIl-Ncol that cut at start site the exon-1 of the rice CaM-2. DNA fragments was ligated to generate pMB 302 in which the RCaM-2 promoter gene linked to the GUS gene in the same reading frame to form a fusion protein. 


\section{Results and Discussion}

\section{Construction of the RCAM-2 promoter GUS fusion gene}

The CaM genes from the rice genomic library have been isolated and sequenced[6]. RCAM-2 promoter-GUS fusion gene was constructed using a promoter expression vector system (Fig. 1). Ti binary vector pBI101.2 containing the $\beta$ -glucuronidase (GUS) reporter gene was digested with HindIII-SmaI, which is located at the upstream region of the GUS gene. The RCaM-2 promoter was digested with HindIII$\mathrm{Ncol}$ that cut at start site the exon- 1 of the rice CaM-2. The DNA fragment was ligated to generate pMB 302 in which the RCaM-2 promoter gene linked to the GUS gene in the same reading frame to form a fusion protein.

Tissue specific expression of RCaM promotersGUS fusion gene in transgenic plants

We have previously reported that calmodulin gene expression in transgenic tobacco plants was developmentally regulated using $\mathrm{RCaM}$ promoter-CAT fusion molecules[7]. To further investigate the expression of calmodulin promoter, GUS activity in transgenic tobacco plants with the rice RCaM-2 promoter-GUS fusion gene was carried out with $X$-glucuronidase as the chromogenic substrate. RCaM-2 promoter was preferentially expressed in specific tissues of organ, including stem apex, root tip and vascular tissues of young plants (Fig. 2). The RCaM-2 promoter activity was differentially expressed in various organs during development. During plant growth, the activity of RCaM-2 promoter was significantly reduced.

Histochemical staining for GUS activity in transgenic tobacco with the RCaM-2 promoter-GUS fusion gene in the transverse (Fig. 2A, D) and longitudinal sections (Fig. 2B, C) of stem and petioles was restricted to the inside of the vascular system, and the cortex and epidermis located of the vascular system usually did not show GUS staining even a plant that expressed strong activity.

Transverse sections of the root tip in transgenic tobacco with the RCaM-2 promoter-GUS fusion gene taken at two zone along the root were prepared (Fig. 3). Histochemical localization with the RCaM-2 promoter-GUS fusion gene revealed that in the region where the metaxylem vessel members began to differentiate expression was apparent in epidermis and meristem cortex. In more proximal parts of the root expression gradually decreased.

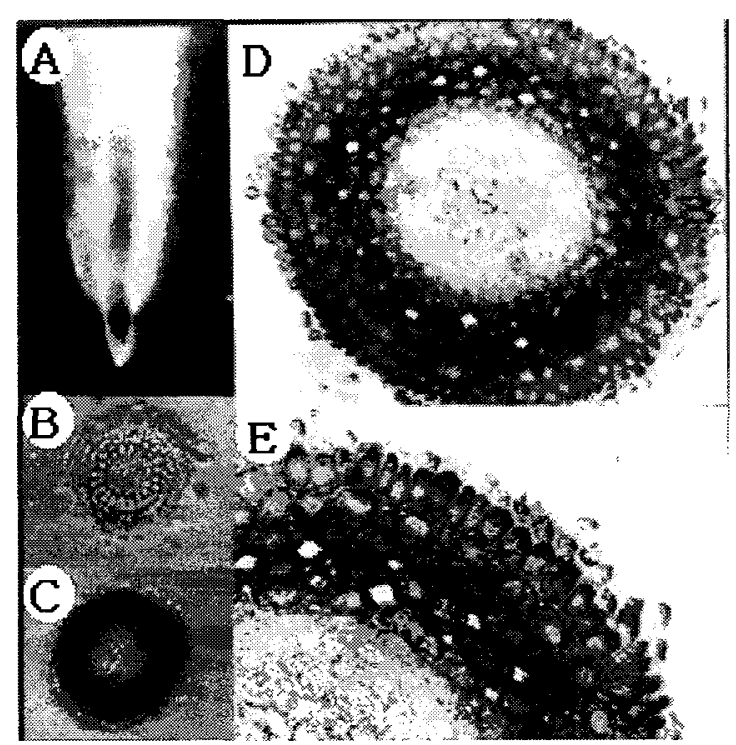

Fig. 3. Histochemical localization of expression of GUS activity in root tip of tobacco plants transformed with RCaMGUS fusion gene. A, root tip; B, transverse section of root; $C$, transverse section of root tip; D, E, expended picture of transverse section of root tip $(3 X, 5 X)$ respectively.

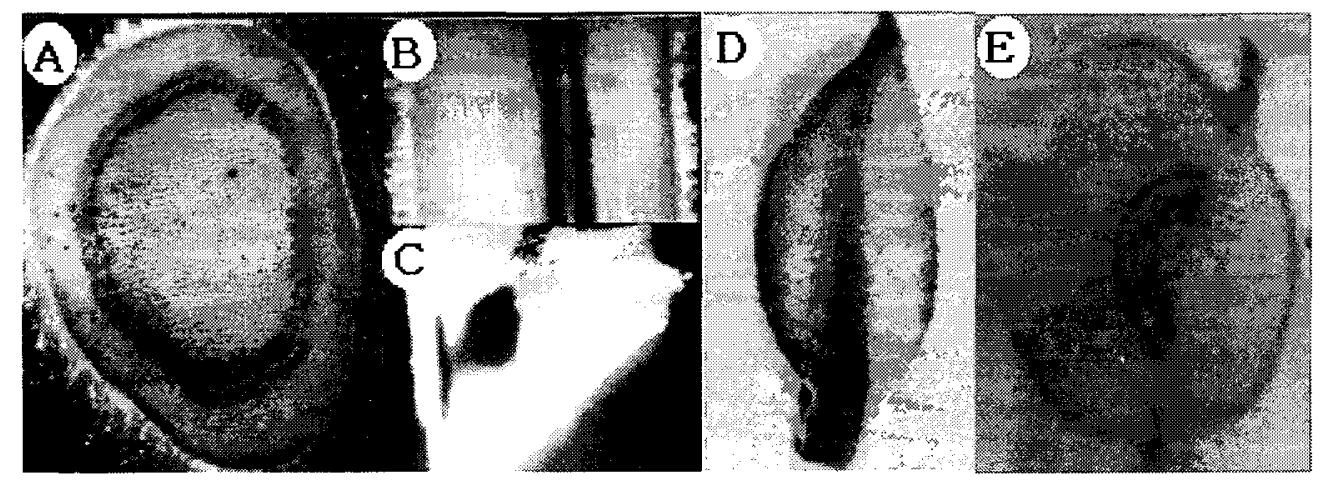

Fig. 2. Histochemical localization of expression of GUS activity in stems and petioles of transgenic tobacco plants harboring RCaM promoter-GUS fusion gene. A, transverse section of stem; B-C, longitudinal section of stem and axillary bud. D, young leave; $\mathrm{E}$, transverse section of petioles. 
The promoter regions of the different CaM genes have been analyzed (Table 1). Several putative transcription factor sites such as a GC box, a TATA-like box, a cyclic AMP response element $(\mathrm{RE}$ ) and several AGGGA elements have been identified, however the elements responsible for their strong co-expression, and even those providing different spatial and temporal control, remain to be elucidated.

The effect of wounding on activation of RCaM-2 promoter

The induction of the RCaM-2 promoter-GUS reporter gene in response to wound was confirmed by histochemical staining of the transgenic tobacco plants. As shown in Fig. 4, RCaM-2 promoter in young (upper) leaves was strongly induced by wounding, however little was induced in matured (lower) leaves. GUS activity was dramatically induced within $5 \mathrm{~min}$ after wounding and reduced after $2 \mathrm{~h}$. In petal, stamina and petioles, the induction of RCaM-2 promoter was observed in response to wound (Fig. 4C-F). High GUS activity was detected young stem and petioles, whereas old leaves was dramatically reduced. An interesting result was found that GUS activity did not detected in leaves blade but the activity was highly induced $5 \mathrm{~min}$ after wounding. Especially, GUS activity is high in meristemic tissues correlated with active s cell division[26,30]. These results suggest that 5 'flanking region of $\mathrm{RCaM}-2$ controls developmental, tissue specific and wound-induced expression.

In view of the role $\mathrm{Ca}^{2+}$ plays in mediating plant responses to biotic[17] and abiotic[15] stimuli, it is not surprising that $\mathrm{CaM}$, as an important cellular $\mathrm{Ca}^{2+}$ modulator, is involved in mediating these responses. Table 2 indicates the evidence for the involvement of CaM in plant

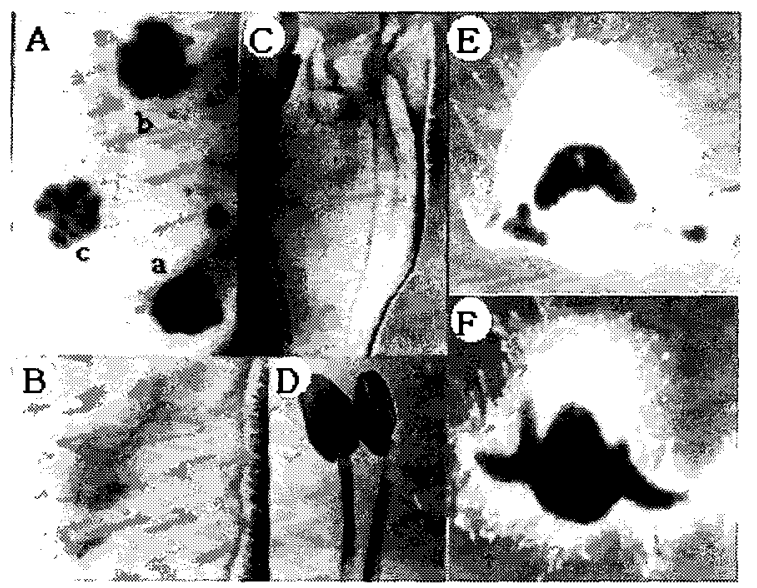

Fig. 4. Expression of RCaM promoter-GUS fusion gene in response to wound. $\mathrm{A}$, young (upper) leaf ; B, old (lower) leaf; C, petal; D, stamina; E, F, petioles. Young leaf was wounded in vivo conditions for 5(a), 30(b), and $120(\mathrm{c}) \mathrm{min}$. Other organs were wounded in vivo conditions for $5 \mathrm{~min}$.

Table 1. Comparison of putative promoter sequences of rice CaM genes (RCaM-1 and RCaM-2) with those of other CaMs

\begin{tabular}{|c|c|c|c|c|c|c|}
\hline Gene & TATA box & CAAT box & GC rich region & CREB/AP-2 & HSE & AGGA \\
\hline Rice CaM-1 & + & - & + & - & - & + \\
\hline Rice CaM-2 & - & + & + & $+/+$ & - & + \\
\hline Soybean CaM-1 & + & + & + & - & - & + \\
\hline Soybean CaM-4 & + & + & + & - & - & + \\
\hline Arabidopsis CaM-3 & + & + & - & $+1+$ & + & - \\
\hline Chlamidomonas & + & - & + & - & + & - \\
\hline Human CaM-III & - & + & + & - & - & + \\
\hline Rat CaM I & + & - & + & - & - & + \\
\hline Rat CaM II & - & - & + & $+/+$ & - & + \\
\hline Drosophila CaM & + & - & + & - & - & + \\
\hline
\end{tabular}

Table 2. Involvement of calmodulin in plant responses to touch and wound

\begin{tabular}{|c|c|c|}
\hline CaM, CaM-like genes & Type of evidence & Reference \\
\hline RCaM-2(rice) & gene expression ${ }^{1)}$ & This research \\
\hline PCM1(potato) & gene expression $\left.{ }^{2}\right)$ & {$[30]$} \\
\hline TCH CaM-like genes (Arabidopsis) & gene expression ${ }^{2)}$ & [5] \\
\hline $\mathrm{NtCaM}-1,2,3$ and 4 (tobacco) & gene expression ${ }^{1,2)}$ & {$[21]$} \\
\hline MBCaM-1(Mung bean) & gene expression ${ }^{2}$ & [2] \\
\hline NpCaM-1(Nicotiana plumbaginifolia) & gene expression ${ }^{2}$ & [31] \\
\hline
\end{tabular}

${ }^{1)}$ Promoter activity analysis, ${ }^{2)} \mathrm{mRNA}$ analysis 
responses to wound signal. RCaM-2 promoter was developmentally regulated and expressed in response to stresses such as hormones and wound signal.

\section{References}

1. Bergey D. R. and C. A. Ryan. 1999. Wound- and systemininducible calmodulin gene expression in tomato leaves. Plant Mol. Biol. 40, 815-823.

2. Botella, J. R. and R. N. Arteca. 1994. Differential expression of two calmodulins in response to physical and chemical stimuli. Plant Mol. Biol. 24, 757-767.

3. Braam, J. and R. W. Davis. 1990. Rain-, wind-, touch-induced expression of calmodulin-related genes in Arabidopsis. Cell 60, 357-364.

4. Braam, J. 1992. Regulated expression of the calmodulinrelated TCH genes in cultured Arabidopsis cells: Induction by calmodulin and heat shock. Proc. Natl. Acad. Sci. USA 89, 3213-3216.

5. Braam, J., M. L. Sistrunk, D. H. Polisensky, W. Xu, M. M. Purugganan, D. M. Antosiewicz, P. Campbell and K. A. Johnson. 1997. Plant responses to environmental stress: regulation and functions of the Arabidopsis TCH genes. Planta 203, S35-S41.

6. Choi, Y. J., C. O. Lim, P. G. Shin, S. W. Gal, J. D. Bahk, G. An and M. J. Cho. 1993. Structural organization and sequence analysis of the calmodulin from rice (Oryza sativa cv. IR36). Mol. Cells 3, 255-261.

7. Choi, Y. J., E. K. Cho, S. I. Lee, C. O. Lim, S. W. Gal, M. J. Cho and G. An. 1996. Developmentally regulated expression of the rice calmodulin promoter in transgenic tobacco plants. Mol. Cells 6, 541-546.

8. Dong, A., H. Xin, Y. Yu., C. Sun, K. Cao and W.-H. Shen, 2002. The subcellular of an unusual rice calmodulin isoform, OsCaM61, depends on its prenylation ststua. Plant Mol. Biol. 48, 203-210.

9. Gawiennowski, M. C., D. Szymanski, I. Y. Perera and R. E. Zielinski. 1993. Calmodulin isoforms in Arabidopsis encoded by multiple divergent mRNAs. Plant Mol. Biol. 22, 215-225.

10. Geiser, J. R., D. van Tuinen, S. E. Brockerhoff, M. M. Neff, and T. N. Davis. 1991. Can calmodulin function without binding calcium? Cell 65, 949-959.

11. Heo, W. D., S. H. Lee, M. C. Kim, J. C. Kim, W. S. Chung, H. J. Chun, K. J. Lee, C. Y. Park, H. C. Park, J. Y. Choi and M. J. Cho. 1999. Involvement of specific calmodulin isoforms in salicylic acid-dependent activation of plant disease resistance responses. Proc. Natl. Acad. Sci. USA 96. 766-771.

12. Hoekema, A., P. R. Hirsch, P. J. Hooykaas and R. A. Schilperoort. 1983. A binary plant vector strategy based on separation of the Vie- and T-region of the Agrobacterium tumefaciens Ti plasmid. Nature (London) 303, 179-180.

13. Jefferson, R. A. 1987. Assaying chimeric genes in plants: the GUS gene fusion system. Plant Mol. Biol. Rep. 5,
$387-405$

14. Jena, P. K., A. S. N. Reddy and B. W. Poovaiah. 1989. Molecular cloning and sequencing of a cDNA for plant calmodulin: Signal-induced changes in the expression of calmodulin. Proc. Natl. Acad. Sci. USA 86, 3644-3648.

15. Knight, H. 2000. Calcium signaling during abiotic stress in plants. Internal Reviews of Cytology 195, 269-324.

16. Koltunow, A. M. J. Truettner, K. H. Cox, M. Wallroth and R. B. Goldberg. 1990. Different temporal and spatial gene expression patterns occur during anther development. Plant Cell. 2, 1201-1224

17. Lavine, A. R., I. Pennell, M. E. Alvarez, R. Palmer and C. Lamb. 1996. Calcium mediated apoptosis in a plant hypersensitive disease resistance response. Current Biology 6, 427436.

18. Lee, S. H., J. C. Kim, M. S. Lee, W. D. Heo, H. Y. Seo, H. W. Yoon, J. C. Hong, S. Y. Lee, J. D. Bahk, I. Hwang and M. J. Cho. 1995. Identification of a novel divergent calmodulin isoform from soybean which has differential ability to activate calmodulin-dependent enzymes. J. Biol. Chem. 270, 21806-21812.

19. Lee, S. H., H. Y. Seo, J. C. Kim, W. D. Heo, W. S. Chung, K. J. Lee, M. C. Kim, Y. H. Cheong, J. Y. Choi, C. O. Lim and M. J. Cho. 1997. Differential activation of NAD kinase by plant calmodulin isoforms. J. Biol. Chem. 272, 9252-9259.

20. Lee, S. H., M. C. Kim, W. D. Heo, J. C. Kim, W. S. Chung, C. Y. Park, H. C. Park, Y. H. Cheong, C. Y. Kim, S.-H. Lee, K. J. Lee, J. D. Bahk, S. Y. Lee and M. J. Cho. 1999. Competitive binding of calmodulin isoforms to calmodulinbinding proteins: implication for the function of calmodulin isoforms in plants. Biochim. Biophys. Acta 1433, 56-67.

21. Ling, V. and R. E. Zielinski. 1989. Molecular cloning of cDNA sequences encoding the calcium-binding protein, calmodulin, from barley. Plant Physiol. 90, 714-719.

22. Ling, V., I. Y. Perera and R. E. Zielinski. 1991. Primary structures of Arabidopsis calmodulin isoforms deduced from the sequences of cDNA clones. Plant Physiol. 96, 1196-1202.

23. Murashige, T. and F. Skoog. 1962. A revised medium for rapid growth and bio assay with tobacco tissue cultures. Physiol Plant 15, 473-497

24. Pandy, S., S. B. Tiwari, K. C. Upadhyaya and S. K. Sopory. 2000. Calcium signaling: linking environmental signals to cellular functions. Crit. Rev. Plant Sci. 19, 291-318.

25. Perera, I. Y. and R. E. Zielinsk. 1991. Structure and expression of the Arabidopsis CaM-3 calmodulin gene. Plant Mol. Biol. 19, 49-64.

26. Perera, I. Y. and R. E. Zielinski. 1992. Synthesis and accumulation of calmodulin in suspension cultures of carrot (Daucus carota L.). Plant Physiol. 100, 812-819.

27. Rodriguez-Concepcion, M., S. Yalovski, M. Zik, H. Fromm and W. Gruissem. 1999. The prenylation status of a novel plant calmodulin directs plasma membrane or nuclear localization of the protein. EMBO J. 18, 1996-2007.

28. Sambrook, J., E. Fritsch. and T. Maniatis. 1989. Molecular Cloning : A Laboratory Mannual, 2nd ed., Cold Spring Harbor Laboratory Press, Cold Spring Harbor, New York. 
29. Snedden, W. A. and H. Fromm. 1998. Calmodulin, calmodulin-related proteins and plant responses to the environment. Trends Plant Sci. 3, 299-304.

30. Takezawa, D., Z. H Liu, G. An and B. W. Poovaiah. 1995. Calmodulin genes family in potato: developmental and touch-induced expression of the messenger-RNA encoding a novel isoforms. Plant Mol. Biol. 27, 693-703.

31. Van Der Luit A. H., C. Olivari, A. Haley, M. R. Knight, A. J. Trewavas, 1999. Distinct calcium signaling pathways regulate calmodulin gene expression in tobacco. Plant Physiol. 121, 705-714.

32. Xiao, C., H. Xin, H., A. W. Dong, C. R. Sun and K. M. Cao. 1999. A novel calmodulin-like protein gene in rice which has an unusual prolonged C-terminal sequence carrying a putative prenylation site. DNA Res. 6, 179-181.
33. Yamakawa, H., I. Mitsuhara, N. Ito, S. Seo. H. Kamada and Y. Ohashi. 2001. Transcriptionally and post-transcriptionally regulated response of 13 calmodulin genes to tobacco mosaic virus-induced cell death and wounding in tobacco plant. Eur. J. Biochem. 268, 3916-3929.

34. Yang, T., G. Segal, S. Abbo, M. Feldman and H. Fromm. 1996. Characterization of the calmodulin gene family in wheat: structure, chromosomal location, and evolutionary aspects. Mol. Gen. Genet. 252, 684-694.

35. Yang, T., S. Lev-Yadun, M. Feldman and H. Fromm. 1998. Developmentally regulated organ-, tissue, and cell-specific expression of calmodulin genes in common wheat. Plant Mol. Biol. 37, 109-120.

36. Zielinski, R. E. 1998. Calmodulin and calmodulin-binding proteins in plants. Annu. Rev. Plant Physiol. and Plant Mol. Biol. 49, 697-725.

\section{초록 : 상처에 의해서 유도되는 벼 calmodulin promoter의 transgenic 담배에서조직 특이적 발현}

\section{최 영 주*}

(신라대학교 식품영양학과)

Calmodulin 유전자의 발현 조절을 연구하기 위해, 벼 calmodulin promoter (RCaM-2)를 분리하여 GUS (report 유전자)에 윱합하였다. GUS 활성은 정단조직, 근단 및 관다발 영역과 같은 성장조직에서 높게 발현되었다. 줄기 와 페티올의 transverse 절단부위 GUS 활성은 관다발계의 안쪽에 제한되었으며 관다발계의 외부에 위치한 피층 과 표피에서는 강하게 발현된 식물에서도 GUS 활성이 나타나지 않았다. GUS 활성은 어린 조직에서 특이적으로 발현되었으며 상처에 의해서 신속하게 증가하였다. RCaM-2 promoter는 세포분열이 왕성한 어린조직이나 생장 점에서 강하게 발현되며 mechanical 신호에 의해서 현저히 유도되었다. 이러한 결과는 RCaM-2 유전자의 $5^{\prime}$-flanking 영역이 상처에 의해서 유도되는 발현을 조절하는 것으로 추정된다. 